\title{
Multiculturalism and America
}

\author{
Çokkültürlülük ve Amerika
}

\author{
Emel ÖZDEMIR'
}

\begin{abstract}
In the new world order that has begun to be restructured, how national identities will be carried out together and how differences will be transformed into benefits, instead of problems has become a very important issue in terms of ensuring peace and prosperity in every society. The USA realized that they could no longer pursue the understanding of Americanism, based on a single American identity. America, where many different cultures live, has inevitably had to follow a policy which respects every culture and is based on cultural pluralism. In contrast to cultural diversity in the USA, it is possible to point out that racism, which did not stop under Obama, was endured with Trump's presidential process among the different positions of low-income black and minority societies. In this study, the question of whether new president of USA, Joe Biden is going to attempt to vary the otherization policy for the minority societies and immigrants which was maintained in the process of Trump's presidency, or not is aimed to be made out, by analyzing the news about the minority societies and immigrants in CNN (USA) throughout two months, December, 2020 and January, 2021 though the discourse analysis method.
\end{abstract}

Keywords: Multiculturalism, America, CNN, Minorities

\section{Öz}

Tüm dünyada yeniden yapılandırılmaya başlanan yeni dünya düzeninde, milli kimliklerin nasıl bir arada yaşayacakları ve farklılıkların sorunlardan ziyade nasıl faydaya dönüştürüleceği, her toplumda barışın ve refahın sağlanması açısından çok önemli bir konu haline gelmiştir. ABD, artık korumayı amaçladığı ve tek bir Amerikan kimliğine dayanan Amerikancılık anlayışını artık sürdüremeyeceğini anlamıştır. Pek çok farklı kültürün beraber yaşadığı Amerika, kaçınılmaz olarak; her kültüre saygı duyan ve kültürel çoğulculuğa dayanan bir politika izlemek zorunda kalmıştır. ABD mevcut olan kültürel çeşitliliğin aksine, Obama döneminde de durmayan ırkçılığın, düşük gelirli siyah ve azınlık toplumlarda, Trump'ın başkanlık süreciyle katlanarak arttığını söylemek mümkün olacaktır. Çokkültürlülük ve Amerika başlıklı bu çalışmada, ABD'nin yeni başkanı olan Joe Biden'ın, bir önceki başkaını Trump'ın başkanlığı süreci boyunca sürdürülen azınlık toplumlara ve göçmenlere yönelik ötekileştirme politikasını değiştirip, değiştirmeyeceği sorusunun, CNN (ABD) gazetesinde yer alan Aralık, 2020 ve Ocak 2021 sürecindeki azınlık topluluklar ve göçmenlerle ilgili haberlerin söylem analizi metoduyla analiz edilerek yanıtlanması hedeflenmektedir.

Anahtar Kelimeler: Çokkültürlülük, Amerika, CNN, Azınlıklar

Araștırma Makalesi (Research Article)

Gönderim Tarihi (Received): 25.02 .2021

Kabul Tarihi (Accepted): 11.03.2021
Atıf (cite as): Özdemir, E. (2021). Multiculturalism and America.

Akdeniz Üniversitesi Iletișim Fakültesi Dergisi, 35, s. 112-125, D0I: 10.31123/akil.886539 


\section{Introduction}

Today, as a result of globalization and restructuring social structures, the separation of borders between countries with clear lines has been left aside, radical changes have occurred in the economic, social, commercial, political and ideological structures of societies and the effects of different cultures have begun to be experienced in every field. In addition, new trends and changes have begun to be encountered in many areas in societies and the world has become a global environment where different cultures live together. As a result, in the world, dominated by multiculturalism, the issue of "how a society should be structured and how different identities should live together" came to the fore. As it is understood, in the new world order that has begun to be restructured, how national identities will be carried out together and how differences will be transformed into benefits instead of problems has become a very important issue in terms of ensuring peace and prosperity in every society. The reason is behind is that some societies that fail to show the correct approach to cultural difference will have to deal with the serious problems, created by the multiculturalism that they face, since they can not turn the differences into an enriching and advantageous factor. For this reason, it is very important how we should organize the multicultural world structure, which is now a reality of the world. Uniting people with different cultural characteristics and abilities around common values, excluding them and not seeing them as the "other", making multiculturalism as an advantage can be achieved in every field in the society. For this reason, every society should think about what kind of social structure it should create, taking into account the internal diversity and people from different cultures, coming from abroad for reasons, such as immigration. The reason behind is that, today's world has turned into a global environment that includes differences. These people who are the reality of the global world and who want themselves to be accepted and respected maintain a policy of recognition in a sense in order to exist in the society and protect their reputation without having to give up the choices that they make of their own free will.

As it can be understood from its name, the concept of multiculturalism continues its policy, based on the differences and diversities related to culture, not only an individual choice and diversity. That is, the concept of multiculturalism is associated with differences that are fused with culture or even have a meaning and significance from the past. Although some societies try to ignore the concept of multiculturalism from time to time, almost the whole world has met this situation. Until now, every society that has only dealt with its own national cultures has perceived the multiculturalism situation differently and adapted it to its lifestyle by interpreting it, accordingly. However, the only truth that every society is aware of and has to face is that they have to accept multiculturalism. For example, the United States realized that they could no longer pursue the understanding of Americanism, based on a single American identity, which they aim to protect. Black struggles in the United States acquired a cultural characteristic in the 1960s; many of the leaders of the movement insisted on the preservation and recognition of their culture. America, where many different cultures live, has inevitably had to follow a policy which respects every culture and is based on cultural pluralism. Apart from these countries, many world countries such as England, Germany, France have increasingly had to recognize multiculturalism and accept it willingly or compulsively. In addition, when we examine societies with a multicultural structure, consisting of differences in the present and the past, some differences are observed. In the past, it is seen that the dominant cultural structure in societies was accepted without questioning. In these societies, those who were minorities could only enjoy as much freedom as they were allowed to. Nowadays, people, belonging to other cultures in multicultural societies struggle to at least get their rights, even if they do not always have all their 
rights. A new cultural and political climate has been formed by increasing interaction and sharing between cultures in contemporary multicultural societies. Not only economic, but also cultural factors have gained importance in societies. In this way, people have understood the concept of culture, how important it is for the development of their societies, how it shapes the social structure and that the cultural values of a society enable it to gain respect and reputation among other cultures. Thus, culture has become a politically important category. Besides, economic and cultural globalization has connected contemporary multicultural societies. In other words, people communicate with other cultures in order to follow the advancing technology and information age. It would be logical to evaluate the concept of globalization, where cultural values come to the fore and where all societies are increasingly intertwined. People communicate more quickly and easily thanks to the developing transportation and communication network and globalization plays a major role in these great changes in today's world. This is because of the fact that the globalizing world is developing more and more rapidly, it is necessary to have the necessary equipment to keep up with its pace. According to Köseoğlu (2002), nowadays, everything, everyone are on the move and many tasks have to be done at a certain pace. Human beings grasp life, fixed motions, such as the sun and the moon within the limits of our biological existence. Despite these sources that we refer to remain constant, our movements increase immensely and gain momentum, requiring us to live much more intensely within the same time period (Köseoğlu, 2002, p. 111). At the same time, with the development of technology, the rate of displacement of international capital has increased. As for Bauman (2006), the speed of information transfer, the internet system are established worldwide and many other technological developments are examples that can explain the dimensions of globalization today (Bauman, 2006, p. 22).

The concept of diversity, which is an inevitable feature of societies with the globalization is important, because it will lead to different and new experiences by being aware of different options in every field and it must be accepted in every society. Since human beings can not recognize diversity for a while, it is nice to have difference, even if it is not for the better. The reason is behind is that here there is no diversity, it is an inevitable result to encounter ordinary and boring situation. That is, finding and increasing diversity at all levels will cause people to think from a broader perspective and to be more creative. As it turns out, cultural diversity has become a permanent feature of human life and it will continue, because humans remain curious, creative, dreamy and capable of pushing the limits of their knowledge and experience. In other words, it is inevitable to encounter a situation of diversity wherever people are living. What matters is how the diversity in each field can be transformed into richness and usefulness. Some Sophists, such as "Vico, Montesquieu, Herder" express some understandings that they have built on "culturalism" or "pluralism" in order to ensure harmony and integration in culturally diverse societies. According to these views, people are formed together with culture, changing from culture to culture, they have very few common characteristics, originating only from the species. In addition, "Vico, Montesquieu, Herder" criticize the understanding of monism which sees differences as the expression of perversions, moral illnesses and form their theories, based on the concepts of culture, diversity and they express important ideas in the name of pluralism. It is argued by these thinkers that societies with cultural diversity should be shaped by paying attention to the situation of cultural pluralism. According to Vico (1984), who has expressed his views on cultural pluralism, people have a common nature at the beginning of their history. During their development, they acquired new abilities and changed their original nature accordingly. In his view, human history has lived through three different eras, each representing 
new human abilities, temperaments, management styles and social structures (Vico, 1984, p. 31). As it turns out, according to Vico, each society is a cultural community with different traditions, characteristics and although it initially had a common human nature with others, it has changed its nature as a result of its cultural characteristics and has shaped it according to itself. For another thinker, Montesquieu (1959), cultural diversity is a common and inevitable feature of human life. No society is alike. Each has different traditions, customs, manners, legal systems, family structures, forms of governance and all promoted different passions, moral virtues, temperament traits, forms of perfection and understanding of the well-being. Although not every society has a unique nature, it develops a distinct national genius or spirit that have an independent influence on social institutions, mores and unify them into a coherent whole (Montesquieu, 1959, p. 293). That is, contrary to the monists, according to Montesquieu, the nature of people is reconstructed by their culture and they give people new, original features, skills and values in every respect. Having important views in the name of cultural pluralism, Herder rejected the monist view that cultures are various by the products of a universal common nature and suggested that human nature is a soft piece of clay, shaped by different cultures in different ways. Also, for Herder (1969), every culture have an unique, wonderful, inexplicable, indestructible identity. All cultures have a different view of human life, realized different human abilities, nurtured different virtues and temperaments and have their own unique happiness essences, centers of gravity, souls, worldviews or atmospheres. Each culture is a self-sufficient and unified whole. (Herder, 1969, p. 181). As it is understood, Herder who likes culture to self-sufficient amoebas, expresses clearly that he does not approve of intercultural diversity by advocating the self-sufficiency of cultures, while attaching importance to cultural diversity. For Herder, all cultures are unique expressions of the human spirit and are incommensurable; like flowers in the garden, they complement each other beautifully, contributing to the wealth of the world (Lovejoy, 1961, p. 299). For this reason, in order for the flowers in the garden to remain as they are, each of them should be placed side by side with their own beauty and should not be confused with each other.

Although the situation of multiculturalism has been met with harsh criticism from time to time and policies have been developed to not accept it in most societies, it emerges as a reality that the globalizing world has to face. For this reason, societies with increasing cultural diversity are trying many methods to protect their social order and integration. In order to eliminate the differences in some societies and provide a national unity, some adaptation models are attempted for implementation such as the Anglo-adaptation model, the Melting Pot... etc. In other words, today, different approaches are encountered in the structuring of societies, in which people from different religions, languages, races and cultures live together. In these societies with a multicultural structure, it is ensured that every group in the society is welcomed with respect, tolerance and can live under equal conditions with other groups, by accepting the understanding of multiculturalism. But, from a monoculturalist or assimilationist point of view, each group other than the dominant culture is suppressed and forced to live a life against their will. In multicultural societies, one of the policies, carried out in order to ensure the order and harmony of the society is assimilation. The assimilation policy which stands against multiculturalism appears as an attitude that aims to ensure that all the minority societies and immigrants live a life in accordance with the needs of the nation, by being treated in a way that ensures the continuation of only the dominant culture in the society.

The news in CNN (USA) about the minorities and immigrants are studied in the process of Biden's presidency and it is aimed to understand Joe Biden's new policy for the minority societies and immigrants. The feeling of racism and discrimination does not change, but the expression of it 
is changing. Obama became president and he was introduced as the first black president, but there is a distinction there. Obama's father is a black from Kenya and he's not originated from Blacks, coming from slavery as others. So, some Blacks didn't approach Obama as themselves. Whites also tolerated him. He was a Black president, but many people can't really call it an AfricanAmerican president in that context. But, when he was president, the police violence continued. It was a haunted thing. Since Trump came, the state's aggressive attitude has become more and more visible. People raided the municipalities with guns, but Trump called these armed people, as they are good people. Trump explicitly said to the unarmed, peaceful protesters, if you don't stop it, you think we're going to shoot you. So, these discourses increased the courage of those who do this racism. In fact, these events happened during the reign of Democrat Senator Amy Klobuchar, who was a prosecutor at the time, but she did nothing, even though she was a Democrat. It's about not giving them that courage. Even though, people are exposed to racism, they put up with it, but now it's up to the highest level with especially the killing 46-year-old, George Floyd. George Floyd, who was killed by strangling with the words “I can't breathe”, as a result of the police's pressing his neck with his knee for a long time, while he was detained in Minneapolis, Minnesota. He was killed unjustly. Minnesota triggered reactions in the USA where more than 100 thousands people attended. Protests against racism and injustice against minorities, especially Black people do not cease. While the curfews, imposed in many American cities do not seem to calm down the reactions. It is seen that over the years, hundreds of black people have been killed. They were also killed by police officers who were mandated by law to protect them. People have stated to ask how minorities will trust the police now, as after doing these, there was no trust in justice, as they were not punished. They have started to live in fear in their own country. It is not possible to say that all Whites are racists or all cops are racist. For instance, after these incidents, some policemen threw their batons and held the protesters' banners. They walked together. There are these too, and this is something that should happen. The place where things started is like a kind of border, the rich on the one hand and the poor minorities on the other. When the street where the events started are generally analyzed, it is seen the income inequality in the region. Minneapolis is like a border where he majority of the population is Scandinavian and German in general in the Midwest, especially in Minnesota, over time, Blacks, Sudan and Ethiopia, as well as minorities from East Asia joined the high-rise buildings against the large garden houses of the rich. It can be possible to say that minorities in the USA prefer crowded cities, because they do not feel safe.

\section{The Aim of The Study}

In this study, how the new president of USA, Joe Biden is going to do in order to change the otherization policy for the minority societies and immigrants that was experienced in the process of Trump's presidency is planned to be study, by analyzing the news about the minority societies and immigrants in CNN (USA) throughout two months, December, 2020 and January, 2021 though the discourse analysis method. The analysis of news texts, in which reality is reconstructed through "language and discourse" though discourse analysis method is very significant in terms of explaining the explicit and implicit meanings of the discourses, used in the news and the effect that they have on different parts of the society. To be able to reveal the ideological codes in the news, the implicit meanings, carried must be analyzed. In order to see the implicit interpretations of the news, the ways in which ideologies show themselves in the discourse need to be examined in a detailed way. 


\section{The Universe and Sampling of The Study}

In this study, America's press is defined as a universe in research. As a sample; CNN (USA) newspaper has been identified. CNN (USA) which is used as a sample in this study is analyzed, throughout two months, December, 2020 and January, 2021 with the discourse analysis method, mainly in terms of the news about the minority societies and immigrants in CNN (USA).

\section{The Method of The Study}

The analysis of news texts, in which reality is reconstructed through "language and discourse" though discourse analysis method is very significant in terms of explaining the explicit and implicit meanings of the discourses, used in the news and the effect they have on different parts of the society. In general, discourse analysis is a method that aims to analyze media texts ideologically and critically and to reveal the thought behind the texts, based on interpretation. According to Sözen (1999), discourse analysis is an analysis aimed at obtaining information through discovery (Sözen, 1999, p. 86). The theory of Van Dijk will be dealt with in the method of revealing the different perspectives, aimed to be conveyed, by analyzing the news in CNN (USA). According to Van Dijk's analysis method (1998), texts are divided into "macro and micro structures". Macro structures, consist of news headlines, subheadings, news spots, news entries, a thematic structure that aims to reveal which themes follow each other in the news and the schematic structures of these themes. Micro structures covers the discourse of the news about the lexical choices in the news, the structures of the sentences, used and the relationships between these sentences (Van Dijk, 1998, p. 31-45). In addition, according to Van Dijk, ideologies and thought structures in the news can be revealed by the discourse analysis method. In this way, it is a news text that is evaluated with the discourse analysis and information about what is happening in that society in social, political and ideological terms. This is why, according to Van Dijk, the information, represented in the memory is the mental structuring that helps to understand the text. Context model style, according to this specific mental model, organizes discourse's view of communication, by establishing its connection with social situation and structure. As it is understood, all kinds of linguistic, formal, expressive and contextual characteristics of a news text should be examined in detail in order to be understood and to reveal the information that it contains. Because these texts, which are seen as simple news texts from time to time, will transform the society and affect the social structure deeply, as they reconstruct the reality with the ideological ideas and codes that they contain. In other words, the analysis of news texts are not only studied with the relations, at the level of surface structures, but also with the text titles and text relations, their differences from the temporal order in the narrative, especially the created uncertainties and the world knowledge. In addition, As for Ülkü (2004), Van Dijk's discourse and critical discourse studies which bring a different perspective to the production, formation processes as well as the comprehension and interpretation processes of the newspaper reader is a method focused on written news (Ülkü, 2004, p. 371-372). For this reason, when Van Dijk's theory of discourse analysis is considered in general, this theory, unlike many theories, is a method that does not only evaluate texts within themselves and but also examines the in-text properties of texts and the levels of "understanding-interpretation" of those texts in society. The reason is behind that Van Dijk defends the view that discourse is very important in the formation of an ideological perspective in a society. According to Van Dijk (1999), ideology is a form of social cognition, shared by members of a group, class or other social formations (Van Dijk, 1999, p. 340-341). However, according to Van 
Dijk discourse and communication play a central role in the formation and transformation of ideology which is seen as this social cognition. Therefore, according to him, with the structures, strategies and processes of discourse; there is a need for a clear analysis of the specific role that discourse plays in the reproduction of ideologies. The reason is behind that perception is the process of being aware of stimuli or events around an individual and interpreting them.

\section{The Findings of The Study}

In this study, it is aimed to find an answer the question of whether the new president of USA, Joe Biden is going to attempt to vary the otherization policy for the minority societies and immigrants that was maintained in the process of Trump's presidency or not by analyzing the news about the minority societies and immigrants in CNN (USA) throughout two months, December, 2020 and January, 2021 with the discourse analysis method. For this reason, when the news about the policy for the minority societies and immigrants throughout two months, December, 2020 and January, 2021 in CNN (USA) and the discourses, used in these news are analyzed, 18 related news texts are seen in this process. In this study, the analysis of the news about the policy for the minority societies and immigrants and how these evaluated texts reflect the discourses, used in this process are so significant to understand the "ideological point of view" and its reasons. The reason is behind that, the ideological structure of a society about a subject or a person is reflected through "language" and in this sense, "language" is instrumentalized and functions as the windows of societies, opening to the world. With this study, it is going to be seen how the ideologies, bias of America's for the minority societies and immigrants are reflected in CNN (USA) thoughVan Dijk's discourse analysis method. It is possible to see the manipulation with the discourses and expressions of the news about the policy for the minority societies and immigrants. In this way, this analysis aims to study the ideological structure of the news about the policy for the minority societies and immigrants in the newspaper of CNN (USA) throughout two months, December, 2020 and January, 2021 though the discourse analysis method. It is seen that there are 18 news about the policy for the minority societies and immigrants in CNN (USA) in this process.

\subsection{Macro Structure}

In this study, the discourses of the news are analyzed to understand how they reflect the news about the policy for the minority societies and immigrants through images in Joe Biden's new presidential process. In this way, CNN (USA) newspaper which is examined in this study as a sample is going to be analyzed from an ideological perspective and the common perspectives of this newspaper will be revealed. By the use of "language" in the discourses, images, photographs, phrases of CNN (USA) to form a new perspective among people, it is also possible to see the relationship between "language, ideology and discourse" with this analysis. The reason is behind that while the policy for the minority societies and immigrants is constructed in CNN (USA), it is generally the reflection of the language of American society. When the news, primarily constitute the macro structure of the news texts, such as the main headline of the news, the news entries, the way of the main event's handling, the context information, themes, the schematic structure of the themes and the evaluation of the event parties are analyzed, 18 news that are related about the policy for the minority societies and immigrants are seen in this study. 


\section{1. 1. The Headlines of The News in CNN (USA)}

1. How Trump's most consequential policies have changed America (January 17, 2021)

2. Analysis: What does Biden's diverse Cabinet mean for a divided country (January 19, 2021)

3. Bitter, Trump skips chance to say splashy, high-profile farewell (January 19, 2021)

4. Here's what to expect from the Biden administration in the first 10 days (January 20, 2021)

5. Inauguration poet Amanda Gorman: “Words matter” (January 20, 2021)

6. Poet Amanda Gorman says Capitol riot inspired her to write a "message of hope, ingenuity and healing" (January 20, 2021)

7. Obama delivers a message of unity, saying Americans "have more in common than what separates us" (January 20, 2021)

8. President Clinton's message to Biden: "You have spoken for us today. Now you will lead for us" (January 20, 2021)

9. Former President Bush says he is "pulling for" Joe Biden's success (January 20, 2021)

10. Vice President Harris: "We will rise up. This is American aspiration" (January 20, 2021)

11. Chef José Andrés praises Americans stepping up to end hunger crisis: "We need longer tables, not higher walls" (January 20, 2021)

12. Divisive policies and actions from Trump-era that Biden could decide to alter (January 21, 2021)

13. Biden starts fast on immigration by halting border wall and travel ban while embracing DACA (January 21, 2021)

14. The inauguration of Joe Biden (January 21, 2021)

15. Biden and first lady watch massive fireworks display from the White House (January 21, 2021

16. CEOs stepped up during the Trump era. They're not off the hook (January 24, 2021)

17. For Joe Biden, a key challenge in Central America (December 2, 2020)

18. To win in 2020 and beyond, Democrats need to face 1990s truths (December 1, 2020)

When the headlines of the news and the images, used in the news are analyzed to understand whether new president of USA, Joe Biden's policy for the minority societies and immigrants, it is possible to see how the reader get an idea about the content of the news, through each headline. Via the news headlines of CNN (USA) about the policy for the minority societies and immigrants are studied, readers start to have an idea how the minority societies and immigrants are reflected in America in this process. To illustrate, when the headlines of the news that are mostly seen in this process are analyzed in CNN (USA) as; "Chef José Andrés praises Americans stepping up to end hunger crisis: "We need longer tables, not higher walls" (January 20, 2021), Divisive policies 
and actions from Trump-era that Biden could decide to alter (January 21, 2021), Biden starts fast on immigration by halting border wall and travel ban while embracing" (www.cnn.com. access date:30.01.2021), it is seen that the discourses of these news are going to reflect the new policy for the minority societies and immigrants with new president of USA, Joe Biden. In this study, when the discourses of these news are analyzed, it is explicitly made out that new president of USA, Joe Biden is going to be a hope or the minority societies and immigrants in America, unlike the policy of the former president Trump.

In the macro structure part of the method of Dijk's discourse analysis, "news entries" is the other significant section like news headlines, where the summary of the event is given. In the news entry where important information about the incident, the summary of the event, the main event, the main theme of the news text and the gaze of the newspaper regarding the event are given. In this way, the reader who reads news entries has a general idea about the news without reading the whole news. In this study, when the entries of the news about new president of USA, Joe Biden's policy for the minority societies and immigrants are studied, a general idea is obtained as to whether new president of USA, Joe Biden is going to try to change the otherization policy for the minority societies and immigrants. Besides, due to the limitations of the study, in this evaluation, the most prominent entries in the news will take place in this study. For example, in the news of "Divisive policies and actions from Trump-era that Biden could decide to alter" (January 21, 2021), "President Joe Biden assumed the office intent on healing a deeply fractured country and reversing former President Donald Trump's divisive legacy." news entry is seen and an information about "Joe Biden's immigration plan" in this news is given and readers have an idea that new president of USA, Joe Biden is trying to make new policy and change some rules for the minority societies and immigrants that was continued in the process of Trump with this news entry. In addition, in the news of "Biden starts fast on immigration by halting border wall and travel ban while embracing" (January, 21, 2021), the news' entry as 'President Joe Biden kicked off his term by signing out a series of immigration executive actions, moving swiftly to undo many Trump administration policies and ending the national emergency that diverted millions of dollars to the border wall." is seen and it is made out that in this news, Biden's proposed to introduce comprehensive immigration legislation. This news shows that new president of USA, Joe Biden starts to change the policy for the minority societies and immigrants.

When Van Dijk's discourse analysis method deals with the "schematic structure" of the news texts, that is another part of macro analysis criteria, such as the presentation of the main event, the results of the news, the background, the context information, news sources and comments. By reviewing the interpretative criteria, the main event is evaluated. In other words, in the "schematic structure" part of Van Dijk's discourse analysis method, the reader is informed about "how the main event is handled, what the context and background information is and how the comments are made about this news". In addition, it is made out that thematic and schematic evaluations are intertwined and can be handled together in the macro-structure analysis. While studying the news, discussed in CNN (USA) to find an answer to the question of if the new president of USA, Joe Biden is going to attempt to vary the otherization policy for the minority societies and immigrants that was experienced in the process of Trump's presidency, the other significant step in the macro analysis are the "schematic structure" of the event and "contextual information" that are the way of handling the event, background and general evaluation of some important characteristics of the news. In this study, when the discourses and the main subjects of the news are analyzed to understand how new president of USA, Joe 
Biden is going to attempt to vary the otherization policy for the minority societies and immigrants that was continued in the process of Trump with "schematic structure" of the event, some significant themes are mainly seen as; "divisive policies, Joe Biden's immigration plan, healing a deeply fractured country, domestic terrorism, policies and initiatives targeting immigrants and undermining, the nation's progress on civil rights, contrary to his predecessor's anti-immigration rhetoric, Biden's taking directly reverse Trump's policies, Biden's planning to tackle, his decision to alter the Trump-era policies and actions, new policy, involving immigration, equality, The Trump's assault on immigration and "zero tolerance" policy of prosecuting all immigrants who illegally cross the border, immigrant family separations, the separation of thousands of families, including those with infants, Biden's executive actions undo Trump's expansion of immigration enforcement within the USA, Biden's order halted the construction of the border wall, planned by the Trump administration and newly eligible immigrants to file new applications, Biden's reversing the Trump administration's restrictions on passport holders from seven Muslim-majority countries and travel ban on predominantly Muslim countries, Biden's stopping divisive and racist rhetoric with White supremacist language and racist hatred, aimed at immigrants and Latinos, some phrases that Trump had uttered in the past and in a national address days after the shooting, Trump's calling on the nation to condemn racism and White supremacy."

When the wide coverage of the news about the policy for the minority societies and immigrants in CNN (USA) is analyzed, it is seen that some significant issues are told directly or indirectly, by implying in the news' discourses as a historical and contextual information to be able to construct the realities, such as; "Clinton's and Obama's supporting Biden, by saying halting structural inequities within America's democratic system that have accelerated at a breathtaking pace over the course of the Trump's presidency, Biden's saying his administration will reset the policies and practices for enforcing civil immigration laws to align enforcement with these values and confronting the nation's deep-seated racial divisions, Biden's comprehensive immigration legislation to Congress and condemning the "remain in Mexico" policy during Trump, Biden's criticism about Trump's policy that is contributed mercilessly to the disenfranchisement of Black Americans and the exploitation of immigrants, intolerance toward LGBTQ communities and the devaluing of women, especially Black women, in policy and politics, Biden's saying that injustice rooted in racist policies that can no longer be ignored, massaged or ameliorated, The Democratic Party's declaration for the attempt to end systemic racism, entrenched poverty, economic inequality, racial segregation and violence against women, immigrants, the incarcerated and LGBTQ communitinies, Biden's process of repairing a broken country, With Biden, the most racially diverse presidential Cabinet in the history that $50 \%$ of nominees for Cabinet positions and Cabinet-level positions are people of color. That figure includes Vice President-elect Kamala Harris who will be the first Black and South Asian person and first woman to hold the position, substantive change for communities of color, Biden's criticism Trump for the lack of diversity in his Cabinet and his failure to address issues of concern to communities of color, Biden's changing policy for offensive rhetoric to target Muslims, Mexicans, Syrian refugees, Africans, congresswomen of color and Black athletes protesting racial inequality throughout Trump's presidency, Biden's giving up the travel ban, which has been derided by critics as an attempt to ban Muslims from the US and Biden's calling for racial justice and unity in America." When these some significant issues, told directly or indirectly, by implying in the news' discourses as a historical and contextual information to be able to construct the realities are analyzed, it is possible to make out that the new president of USA, Joe Biden is going to attempt to vary the otherization policy for the 
minority societies and immigrants that was experienced in the process of Trump's presidency and be a hope or minority societies and immigrants in America.

\section{2. Micro Structure}

While analyzing the "microstructure" of a news text, the words, sentences, expressions and photographs that make up the texts are evaluated in terms of some criteria, such as "syntatic analysis, regional harmony, word choice and rhetorical analysis" in order to reveal all the elements in CNN (USA). In this study, the news about Biden's policy for the minority societies and immigrants throughout two months, December, 2020 and January, 2021 are evaluated primarily based on the criteria of "syntatic analysis" and "regional harmony" which are the first stage of its microstructure and deal with news texts in terms of their sentences. At the syntatic analysis level of Van Dijk in the micro structure, usage structures of sentences, such as "simple or complex sentences, active or passive establishment" are discussed. When the news about Biden's policy for the minority societies and immigrants during two months, December, 2020 and January, 2021 are analyzed in terms of "syntatic analysis", it is seen that the news about Biden's policy for the minority societies and immigrants are mainly expressed with simple and understandable sentence structures and the reader can easily understand the meaning that is intended to be conveyed, ensuring that the targeted way of thinking reaches the reader precisely. For example, when the news about Biden's policy for the minority societies and immigrants in CNN (USA) on 20 January 2021 are analyzed, it is possible to see mainly simple and understandable sentence structures and the reader can easily understand the meaning that is intended to be conveyed, such as; "Biden will be turning the tide of a majority White and male Trump administration that was only $16 \%$ people of color.", "To overcome these challenges, to restore the soul and secure the future America requires so much more than words." "It requires the most elusive of all things in a democracy: Unity. Unity", "Biden said, speaking from the same platform that had been stormed by armed insurrectionists two weeks ago.", "He acknowledged that speaking of unity can sound foolish these days, but the struggles the nation faces are not new." (www.cnn.com. access date: 30.01.2021).

In addition, while trying to find an answer the question of whether the new president of USA, Joe Biden will make some different attempts to make better life for the minority societies and immigrants that applied in the presidency of Trump, it is examined whether the sentences are formed as "active or passive sentences". It is seen that active sentences are mainly preferred in the news, such as "Biden has achieved a historic feat that observers hope will help begin the process of repairing a broken country. The President-elect has the most racially diverse presidential Cabinet in the history of the US. Americans are demanding leaders atone for the forces of White supremacy that motivated a mob to storm the US Capitol on January 6 in its refusal to accept President Donald Trump's loss. What does Biden's diverse Cabinet mean for a divided country." (www.cnn.com. access date: 30.01.2021) It is seen that "subjects" are brought to the fore and the subject is emphasized, as it is seen in the examples. In this study, in Van Dijk's discourse analysis, another important topic that is examined at micro level is "the choice of words". Since, the words, used in a news texts can be seen as the most effective news item that enables the ideological perspective to be conveyed to the reader by the creator of the text and reshaping the reality in the reader's mind. Therefore, analyzing the words, used in a news text is very important in terms of revealing the ideological thought structures that are both said and implied in the content of the texts. To illustrate, when the news about Biden's policy 
for the minority societies and immigrants are analyzed throughout two months, December, 2020 and January, 2021, it is possible to make out how the discourses of the news are built with some words in CNN (USA) such as; "voting rights legislation, reviving the economy, pushing police reform, Black people, reversing Trump's anti-immigration policies, Civil rights activists, diversity, calling Trump a White supremacist, ensuring vaccine access to underserved communities, supporting voting rights legislation, reviving the economy, recognizing each other's common humanity, having more in common, Biden's looking for what binds them together, working together, discovering doing best when they are all moving in the same direction, Trump's banning Muslims from the US, ending Trump administration's restrictive immigration, blocking barriers on US-Mexico border, calling for racial justice and unity in America, deeply divided by political forces and systemic racism, White supremacy and domestic terrorism, restoring the soul and securing the future America requires, all things in a democracy, unity, the struggles, the nation faces." When these words, used in the news about Biden's policy for the minority societies and immigrants are studied in CNN (USA), it is made out that Biden is planning to vary minority and immigrants policies that was applied in the process of Trump's presidency and Biden wants to reach racial justice and unity in America, unlike Trump.

Another element that is used for increasing the manipulation and effect of the newspapers is the rhetorical elements, such as "using numerical data, expert opinion, showing examples, using photographs and imaginary expressions". To illustrate, in the news of "Divisive policies and actions from Trump-era that Biden could decide to alter" (January 21, 2021), it is seen using numerical data, as the rhetorical elements, such as; "Nearly 55,000 migrants, many of whom are from Central America, have been sent back to Mexico, declaring a national emergency to access additional funds, filing dozens of lawsuits, The current policy restricts entry from 13 countries, On his first day in office, nine of the 17 actions he took directly to reverse rump's policies, a "zero tolerance" policy of prosecuting all immigrants, The policy that ended in 2018, but officials are still scrambling to fix the problems it caused. Last year, lawyers said they haven't been able to reach the parents of 545 children from separated families," As it is seen, by making use of the rhetorical element of "numerical data", the effect of the news on the reader and the power of being believable are increased. Other hetorical elements, such as various photographs are used to increase the impact on the reader in the news about Biden's policy for the minority societies and immigrants and the effect of news is reinforced with these effective photos in the readers' mind:

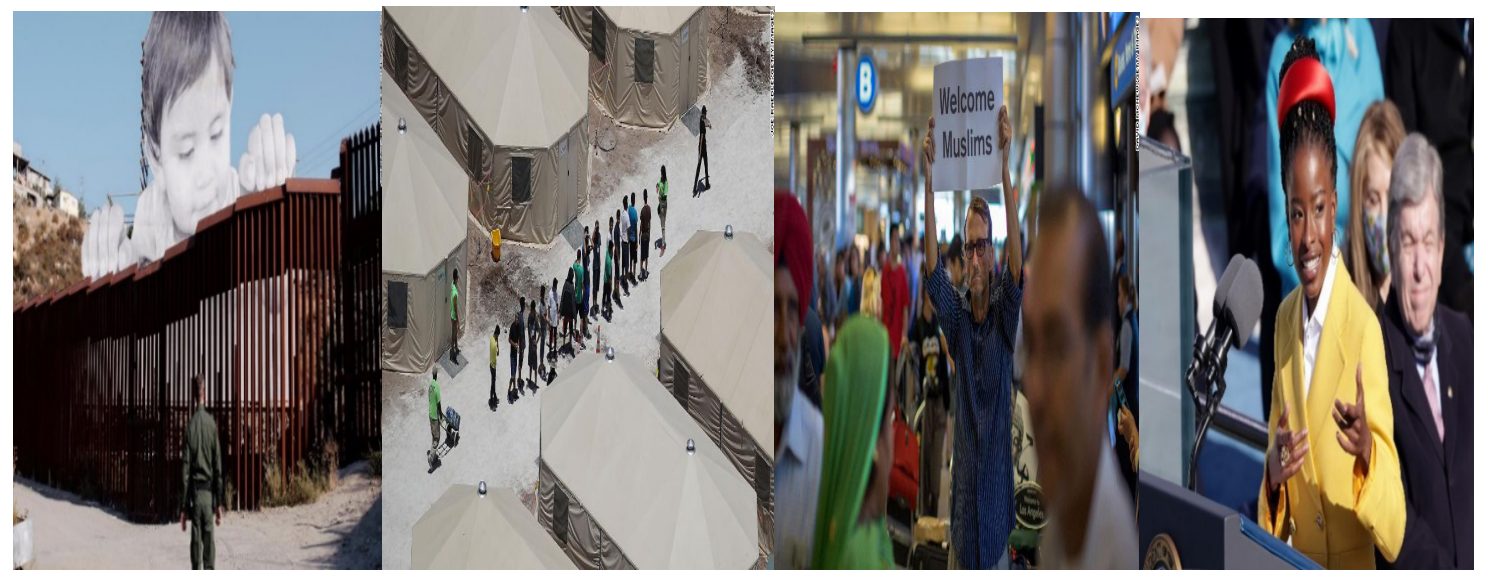

Figure 1: Visual samples from news about the minority societies and immigrants (www.cnn.com, 2021)

When these photographs are examined, it is possible to understand there is going to be radical 
changes in the policy of America for the minority societies and immigrants. The new president of USA, Joe Biden is going to attempt to vary the otherization policy for the minority societies and immigrants that was continued in the process of Trump's presidency. In this study, it is aimed o see how Joe Biden is going to behave to the minority societies and immigrants, by analyzing the news about the minority societies and immigrants in CNN (USA) throughout two months, December, 2020 and January, 2021 though he discourse analysis method.

\section{Conclusion}

In this study, it is aimed o see how new president of USA, Joe Biden is going to behave for the minority societies and immigrants that was experienced in the process of Trump's presidency by analyzing the news about the minority societies and immigrants in CNN (USA) throughout two months, December, 2020 and January, 2021 though the discourse analysis method. In contrast to cultural diversity in the USA, it is possible to point out that racism, which did not stop under Obama, was endured with Trump's presidential process among the different positions of low-income black and minority societies. Since Trump became a president, otherization policy for the minorities has increased and people has started to try to gain their rights. But, as Trump has supported the racism movements, it has increased day by day. People start to torture minorities. So, it is so important to evaluate how the new president of USA, Joe Biden is going to attempt to vary the otherization policy for the minority societies and immigrants that was experinced in the process of Trump's presidency.

When, the policy of Biden for the minority societies and immigrants is evaluated by analyzing the news about the minority societies and immigrants in CNN (USA) throughout two months, December, 2020 and January, 2021 though the discourse analysis method, it is seen that the new president of USA, Joe Biden is going to attempt to vary the otherization policy for the minority societies and immigrants that was continued in the process of Trump's presidency. Biden's discourses are analyzed both macro and microstructure level of Van Dijk's discourse analysis method and it is explicitly seen that Biden is continually giving the message of unity, hope, healing and anti-racism. Biden states that he is going to make radical changes about the issues of housing affordability, income and wealth inequality, criminal justice reform, unemployment and environmental injustice rooted in racist policies, racial segregation and violence against women and immigrants. 


\section{References}

Bauman, Z. (2006). Küreselleşme Toplumsal Sonuçları, İstanbul, Ayrıntı Yayınları.

Herder, J.G. (1968). Reflections on the Philosophy of the History of Mankind. F. Marvel (ed.), Chicago: University of Chicago Press.

Köseoğlu, N. (2002). Küreselleşme ve Milli Hayat. İstanbul: Ötüken.

Lovejoy, A. (1961). The Great Chain of Being: A Study of the History of an Idea. Cambridge: Harvard University Press. Montesquieu, B. (1959). The Sprit of the Laws. New York: The Hafner Library of Classics.

Sözen, E. (1999). Söylem, Belirsizlik, Mücadele, Bilgi/ Güç ve Refleksivite. İstanbul: Paradigma Yayınları.

Ülkü, G. (2004). "Söylem Çözümlemesinde Yöntem Sorunu ve Van Dijk Yöntemi”. Dursun, Ç. (Der.), Haber-Hakikat ve iktidar Ilişkisi, Ankara: Elips Yayınları.

Van Dijk, T. A. (1999). "Söylemin Yapıları ve İktidarın Yapıları". Medya İktidar İdeoloji, Der. ve Çev. Mehmet Küçük, Ark. Van Dijk, T. A. (1998). Ideology, Sage.

Van Dijk, T. A. (1993). "Principles of Critical Discourse Analysis". Discourse and Society, 4 (2).

Vico, G. (1984). The New Science of Giambattista Vico. Çev: T. Bergin, Ithaca: Cornell University Press.

Internet References

www.cnn.com. access date: December, 2020- January, 2021. 